\title{
NON-GOVERNMENTAL ORGANIZATIONS SUPPORTING CSR IN THE CZECH REPUBLIC - ARE THERE ANY LEADERS?
}

\author{
[Nevládní organizace podporující CSR v České republice - jsou zde nějací \\ leadeřir?
}

\author{
Klára Kašparová ${ }^{1}$ \\ ${ }^{1}$ Masarykova univerzita, Ekonomicko-správni fakulta, Lipová 41a, 60200 Brno \\ Email:klarad@econ.muni.cz
}

\begin{abstract}
Following the change in approach of the European Commission to corporate social responsibility (CSR), also the Czech Government had to commence a more intense creation of the national CSR strategy and of the regulative measures supporting socially responsible behavior. During the creation of both of these, the State utilized know-how of non-governmental organizations which had developed much more profound experience with the implementation of CSR in practice. For this reason, the target of this article has become the identification of the leading NGOs with the highest potential to influence further development of the national strategy together with specific form of state measures in this area. In order for the set goal to be achieved, the general scientific methods such as description, comparison and analysis were used. Further, also the SimilarWeb application was used. The performed analysis reveals that currently the youngest of all investigated NGOs - the Association of Social Responsibility - is currently closest to the leading position. It features the widest membership base and established interconnection with the UN Global Compact, the principles of which rank among the most respected frameworks of CSR regulations. Simultaneously, it strengthens its own position by means of a closer cooperation with the Quality Council of the Czech Republic.
\end{abstract}

Keywords: Corporate Social Responsibility, Czech Republic, non-governmental organizations, state regulations.

JEL classification: L31, M14, M38

Doručeno redakci: 10.10.2016; Recenzováno: 19.10.2016; 23.10.2016; Schváleno k publikování: 30.11.2016

\section{Introduction}

Thanks to the activities of the non-governmental organizations (NGO), corporate social responsibility (CSR) in the Czech Republic started to develop already in the beginning of the 1990s. Until the review of the EU CSR Strategy, the Czech Government did not involve extensively and its development was left solely to enterprises and NGOs. In 2011, the European Commission changed its attitude towards CSR. Apart from the managerial concept, CSR is becoming a more and more political concept (Steurer, Martinuzzi \& Margula 2012).

As a Member State of the EU, the Czech Government had to formulate its own national CSR strategy with the consequent gradual creation of such regulations, which would support socially responsible behavior of companies. In creation of both, the State, apart from the consulting voices of other stakeholders, utilized know-how of NGOs, which had developed much more profound experience with putting CSR in practice. With regards to the wording of the National Action Plan for Corporate Social Responsibility we can suppose that the state counts with their support also in the years to come. For this reason, the target of this article has become identification of leading NGOs with the highest potential to influence further development in this area. 


\section{The state of corporate social responsibility in the Czech Republic}

Since 2006, CSR has become a part of the strategic targets of the Quality Council of the Czech Republic (QC CR) - an advisory, initiating and coordinating body of the Czech Government. Until 2012 though, it was not obvious which state body is in charge of CSR for the state part (NIT 2015). This fact only confirms findings of Steurer et al., that governments of the Central and Eastern European countries are not excessively active in support and promotion of CSR (2012). Results of many researches also reveal that it is exactly the lack of government involvement and appropriate regulations, which companies perceive as the key obstacle in adoption of CSR practices (Sopková \& Rašková 2012, Steurer et al. 2012, Dědina \& Dědinová 2013, Skýpalová et al. 2016).

The approach of the Czech Government changed only in 2013 when the patronage over CSR was taken over by the Ministry of Industry and Trade, which, as a consequence of the increasing pressure from the EU, started, together with QC CR and members of its Section for Corporate Social Responsibility, the creation of the National Action Plan for Corporate Social Responsibility in the Czech Republic (NAP). This was consequently approved by the Government of the Czech Republic. It is designed as an open document with its review valid until 2018 (MIT 2015).

CSR policies can be viewed as a complement for hard-law regulations, which allows the Cabinet to launch this way new regulations also in the areas where it seemed politically not desirable or infeasible (Steurer 2010, p. 50; Camilleri 2015, p. 227). Often, these new forms of regulations create environment motivating companies to adopt their social responsibility (Dědina \& Dědinová 2013; Baz, Laguir, Marais \& Staglianò 2016). At the present the Cabinet utilizes especially financial, informational and partnering tools. QC CR acts as the executive body.

Since 2009 it has been organizing the National Award of the Czech Republic for Social Responsibility and Sustainability and the Award of the Regional Governor for Social Responsibility and, since 2015, also the Social Responsibility Award "Do Business Responsibly“. QC CR has also set up the National Informational Portal of CSR and Stakeholder Platform on Corporate Social Responsibility. Since the UN Global Compact's entry to the Czech Republic, it also shows a more intense support of these principles which, apart from others, showed in evaluation of organizations within the National Award, where QC CR dropped its own KORP assessment model and, since 2016, it has been using the International Model Committed to Sustainability developed in cooperation between the UN Global Compact and the European Foundation for Quality Management (NP, n.d.).

Motivating environment is not created by the state itself. It becomes obvious that companies are far more willing to adopt CSR in case they are under a bigger pressure of not only the state but also of NGOs (Brown \& Knudsen 2015). Harangozó and Zilahy (2015) list several reasons of their growing importance in the recent years. Firstly, they are faster in finding solutions to complex social issues owing to their ability to mediate negotiations among multiple subjects of various sectors. Further, they are also able to identify the emerging issues, ease grassroots voice, make the public visibility and importance of issues more intense and to monitor the problem-solving performance (Harangozó \& Zilahy 2015).

\section{Methodology}

The target is to identify the leading non-governmental organization on the CSR field in the Czech Republic. Throughout the period in which the CSR concept has been known in the 
Czech Republic, a number of organizations dealing with CSR has emerged (Kašparová \& Kunz 2013). There was a question which organizations to choose for the purpose of this analysis. Eventually, they were selected from the list of the members of the Stakeholder Platform on Corporate Social Responsibility. By their membership in the Platform, the organizations declare their willingness to discuss the CSR issues, to share the best practices and to take part in further NAP creation (NIP (C) 2015). This was also largely created or commented by them. Based on this fact we can expect increased willingness to take a more intense part in creation of state activities in this area.

Regarding the research target, the selection of organizations for the analysis was carried out using the following criteria - the given organization (1) must be fully devoted to the social responsibility and (2) promotion of CSR must be its key activity. This way, only 4 organizations - Association of Social Responsibility (ASR), Business Leaders Forum (BLF), Business for Society (BfS) and Czech Business Council for Sustainable Development (CBCSD) were analyzed. NAP also explicitly names these organizations as organization devoted to development and promotion of CSR in the Czech Republic next to QC CR (MIT 2015, p.6).

In order for the set goal to be achieved, the general scientific methods such as description, comparison and analysis were used. The SimilarWeb application was used to get the information on the visit rate of the web pages of the analyzed organization. This application allows benchmark of rival web pages with no access to their web analytics (SimilarWeb (C) 2016).

\section{Results}

BLF is the organization with the longest history of involvement in CSR. This organization was the first to present the CSR concept in the Czech Republic. Other organizations were established significantly later. Nevertheless, BfS has longer informal history than the one listed in the table. One of its founders is the Czech Donors Forum, which has been active in the Czech Republic since 1997 and which has been involved in CSR since its very beginning. Its experience, know-how and contacts were thus transferred to BfS - also thanks to the transfer of the Executive Director of Czech Donors Forum to BfS (CDF, n.d.).

Table 1: Comparison of organizations

\begin{tabular}{|l|l|l|l|l|l|}
\hline Name & $\begin{array}{l}\text { Year of } \\
\text { establishment }\end{array}$ & $\begin{array}{l}\text { Number of } \\
\text { members }\end{array}$ & $\begin{array}{l}\text { Avg. } \\
\text { monthly } \\
\text { visits }\end{array}$ & $\begin{array}{l}\text { Interconnection with } \\
\text { other organization }\end{array}$ & Prize award \\
\hline $\begin{array}{l}\text { Association of } \\
\text { Social } \\
\text { Responsibility } \\
\text { (ASR) }\end{array}$ & 2013 & 146 & $3.1 \mathrm{~K}$ & $\begin{array}{l}\text { United Nations Global } \\
\text { Compact } \\
\text { Quality Council of the } \\
\text { Czech Republic }\end{array}$ & $\begin{array}{l}\text { Social Responsibility } \\
\text { Award „Do business } \\
\text { responsibly“ (2015- } \\
\text { now) }\end{array}$ \\
\hline $\begin{array}{l}\text { Business } \\
\text { Leaders Forum } \\
\text { (BLF) }\end{array}$ & 1992 & $\begin{array}{l}74 \text { partners, } \\
47 \text { corporate } \\
\text { members }\end{array}$ & $4.5 \mathrm{~K}$ & $\begin{array}{l}\text { International Business } \\
\text { Leaders Forum } \\
\text { CSR Europe }\end{array}$ & $\begin{array}{l}\text { Futurum Award (1993- } \\
\text { 2012) }\end{array}$ \\
\hline $\begin{array}{l}\text { Business for } \\
\text { Society (BfS) }\end{array}$ & 2010 & $\begin{array}{l}49 \text { members, } \\
2 \text { cooperating } \\
\text { partners }\end{array}$ & $1.5 \mathrm{~K}$ & $\begin{array}{l}\text { Business in the } \\
\text { Community, } \\
\text { CSR Europe, }\end{array}$ & $\begin{array}{l}\text { The Most Responsible } \\
\text { Company Award } \\
\text { (2004-now) }\end{array}$ \\
\hline $\begin{array}{l}\text { Czech Business } \\
\text { Council for } \\
\text { Sustainable } \\
\begin{array}{l}\text { Development } \\
\text { (CBCSD) }\end{array}\end{array}$ & 2012 & 25 & 48 & $\begin{array}{l}\text { World Business Council } \\
\text { for Sustainable } \\
\text { Development } \\
\text { Quality Council of the } \\
\text { Czech Republic }\end{array}$ & N/A \\
\hline
\end{tabular}

Source: the author basing on the information published on the web pages of the analyzed organizations (ASR, C) 2014; BLF, n.d., BfS, n.d.; CBCSD, (C 2016) and SimilarWeb application (C 2016) 
The table 1 shows that the number of members of the organization does not fully correspond with the length of its existence on the market. When comparing the absolute number of subjects without distinguishing between the partner and a corporate member, ASR reports the highest number of members. BLF follows with a small distance. The membership base of BfS represents roughly $1 / 3$ of the ASR's base and the membership base of CBCSD just 1/6.

The analysis of NGO web pages does not show that some organization performed significantly better than the others in basic web metrics. Pages of BLF and ASR have the highest average monthly visit rate, nevertheless, they also have the highest bounce rate $52.13 \%$, and $62.69 \%$, respectively (SimilarWeb (C) 2016) - see table 2. This value does not necessarily have to mean that the contents do not match the visitor's expectations - though e.g. BfS's bounce rate is at the $50 \%$ of their values. During one session, their visitor visits the highest number of pages (SimilarWeb (C) 2016). As far as the bounce rate and an average duration visit are concerned, CBCSD is the best $(0.00 \%$ and 4 min., respectively), which is with the highest degree of probability caused by the fact that their pages keep to be visited mainly by their own members. SimilarWeb data show that the visitors enter this web page directly which distinguishes these pages significantly from the other analyzed webs (SimilarWeb (C) 2016).

Table 2: Comparison of organizations - additional basic web metrics

\begin{tabular}{|l|l|l|l|}
\hline Name & Avg. visit duration & Page/visit & $\begin{array}{l}\text { Bounce } \\
\text { rate }\end{array}$ \\
\hline Association of Social Responsibility (ASR) & $00: 01: 38$ & 2.12 & $62.69 \%$ \\
\hline Business Leaders Forum (BLF) & $00: 00: 47$ & 1.68 & $52.13 \%$ \\
\hline Business for Society (BfS) & $00: 02: 47$ & 5.07 & $30.33 \%$ \\
\hline $\begin{array}{l}\text { Czech Business Council for Sustainable Development } \\
\text { (CBCSD) }\end{array}$ & $00: 04: 00$ & 2.00 & $0.00 \%$ \\
\hline
\end{tabular}

Source: the author basing on results from SimilarWeb application (C 2016)

The table 1 does not describe all partnerships created by the organizations, focusing only on those relating to CSR. All analyzed organizations are somehow connected to the international ones. Nevertheless, just BfS created partnership with the European organizations. Others are connected to the international organizations or they combine both - see BLF. Out of the partnership organizations listed, UN Global Compact has currently the strongest global position. It has the widest membership base and the ten principles formulated by this organization represent one of most widely used used frameworks regulating the socially responsible behavior (Kašparová \& Kunz 2013). Adoption of its ten principles is further supported by the Government itself. ASR also offers the members of UN Global Compact help in composition of the report on progress in compliance with the principles of so-called Communication on Progress, without which it is not possible to maintain a long-term membership in UN Global Compact. All these facts improve the image and bargaining power of ASR, which hosts this network in the Czech Republic.

Only two organizations - ASR a CBCSD - are also connected with QC CR by means of its participation in its Section for Corporate Social Responsibility. We can suppose a stronger connection of ASR as its director is, at the same time, the Chairwoman of this section (NQP (C) 2005-2009). CBCSD is registered only as a regular member. This section is to serve as an expert support of the Stakeholder Platform on Corporate Social Responsibility, whose member base involves all the analyzed NGOs. It is also in charge of coordination and fulfillment of tasks evolving from NAP. Apart from that, it is to support the Global Compact 
Network Czech Republic. This in fact means that it should support ASR, which is its host organization.

Since 2015, ASR, together with QC CR, have been co-organizing the Social Responsibility Award "Do business responsibly". Unlike the rival prize awarded by BfS, it also covers the less focused and newer forms of entrepreneurial activities which start to be more supported (i.e. the family and social businesses). Since 2013, BLF has stopped awarding any prizes for CSR. We have also found no information on any prize awarded by CBCSD.

Based on the comparison of organizations dealing with CSR in the Czech Republic we can state that currently the Association of Social Responsibility is closest to the leading position. Even though it belongs the youngest of all analyzed NGOs, it has managed to build the widest membership base. Its image is further strengthened by its connection with UN Global Compact. The position of ASR was further strengthened by its membership in the Stakeholder Platform on Corporate Social Responsibility as well as by its connection to the Quality Council of the Czech Republic. Due to this fact ASR has a better possibility to influence the development and the specific method of fulfillment of the National Action Plan for Corporate Social Responsibility in the Czech Republic. Its image is also strengthened by co-organization of the Social Responsibility Award "Do business responsibly". Compared to other NGOs, its Internet pages show some space for improvement though.

\section{Conclusion}

Corporate social responsibility was originally brought to the Czech Republic by the nongovernmental organizations and in its beginnings was developed solely by them. The Czech Government neither interfered with its development nor showed any significant support. Due to the membership of the Czech Republic in the EU and thanks to the changed attitude of the European Commission, its attitude had to be reviewed. In the creation of the CSR strategy and related measures, the state used NGOs which had greater experience in its implementation in practice. The state still counts on them, nevertheless based on this analysis we can expect that its cooperation with some of the NGOs will be more intense.

The performed analysis revealed that out of the analyzed NGOs, the Association of Social Responsibility is closest to the leading position and is better poised for closer cooperation with the Czech Government even though it is the youngest organization within this research. To the large extent it is determined by two facts. The Association of Social Responsibility was the only out of the researched NGOs to manage to start cooperation with a foreign partner that attracted attention of the Czech Government. Based on the agreement of the UN Global Compact's entering the Czech Republic, the Government adopted patronage with establishment of the Global Compact Network Czech Republic, it has changed the methodology of evaluation of organizations within the National Award in a way which complies with the requirements of the UN Global Compact and explicitly appeals to Czech corporations to adopt its 10 principles of the National Action Plan. These actions make the Association of Social Responsibility more visible, strengthening its position as a host organization of the UN Global Compact. It provides its members with consulting on launch of these principles within their organizations and motivates them to remain within the Global Compact Network. Due to these facts we can suppose that also in the future the number of its members is going to grow in a more dynamic way than in other NGOs.

The second fact is increasingly closer cooperation and interconnection of the Association of Social Responsibility with the executive body of the Czech Republic Government - the 
Quality Council of the Czech Republic. They co-organize "Do business responsibly", the Chairwoman of the Association of Social Responsibility is at the same time the Chairwoman of the Section for Corporate Social Responsibility of the Quality Council of the Czech Republic and the Chairman of the Quality Council of the Czech Republic is simultaneously a member of Steering Committee of the Global Compact Network Czech Republic. The facts above allow the Association of Social Responsibility to negotiate favorable conditions for its further operations and, at the same time, to have more significant influence on further development and the specific method of fulfillment of the National Action Plan for Corporate Social Responsibility in the Czech Republic than the other researched NGOs.

\section{References}

[1] Association of Social Responsibility, (C) 2014. [website]. [Accessed 20 ${ }^{\text {th }}$ June 2016]. Available from: http://www.spolecenskaodpovednostfirem.cz/

[2] BROWN, D. and J. S. KNUDSEN, 2015. Domestic Institutions and Market Pressures as Drivers of Corporate Social Responsibility: Company Initiatives in Denmark and the UK. Political Studies, 63, 181-201. ISSN 1467-9248.

[3] BUZ, J. E., I. LAGUIR, M. MARAIS and R. STAGLIANÒ, 2016. Influence of National Institutions on the Corporate Social Responsibility Practices of Small- and Medium-sized Enterprises in the Food-processing Industry: Differences Between France and Morocco. Journal of Business Ethics, 134, 117-133. ISSN 1573-0697.

[4] Business for Society, n.d. [website]. [Accessed 15 ${ }^{\text {th }}$ June 2016]. Available from: http://byznysprospolecnost.cz/

[5] Business Leaders Forum, n.d. [website]. [Accessed 15 ${ }^{\text {th }}$ June 2016]. Available from: http://www.csr-online.cz/

[6] CAMILLERI, M. A., 2015. Environmental, social and governance disclosures in Europe. Sustainability Accounting, Management and Policy Journal, 6(2), 224 - 242. ISSN 20408021.

[7] Czech Business Council for Sustainable Development. C) 2016. [website]. [Accessed 15 ${ }^{\text {th }}$ June 2016]. Available from: http://www.cbcsd.cz/

[8] DĚDINA, J. and K. DĚDINOVÁ, 2013. The Development of the Corporate Social Responsibility in Companies in the Czech Republic and Austria During the Last Decade. In Management, Knowledge and Learning International Conference. Zadar: ToKnowPress, p. 107-115. ISBN 978-961-6914-02-4.

[9] HARANGOZÓ, G. and G. ZILAHY, 2015. Cooperation between business and nongovernmental organizations to promote sustainable development. Journal of Cleaner Production, 89, 18-31. ISSN 0959-6526.

[10] KAŠPAROVÁ, K. a V. KUNZ, 2013. Moderní př́istupy ke společenské odpovědnosti firem a CSR reportování. [Modern approaches to corporate social responsibility and CSR reporting]. Praha: Grada. ISBN 978-80-247-4480-3.

[11] Ministry of Industry and Trade. (2015). Národní akční plán společenské odpovědnosti organizací v České republice. [National Action Plan for Corporate Social Responsibility in the Czech Republic]. [online]. [Accessed 20 ${ }^{\text {th }}$ June 2016]. Available from: http://narodniportal.cz/wp-content/uploads/2016/01/Aktualizovan\%C3\%BD-NAP-CSRschv\%C3\%A1len\%C3\%BD-V1\%C3\%A1dou-\%C4\%8CR.pdf 
[12] National Information Portal, (C) 2015. Platforma zainteresovaných stran CSR. [Stakeholder Platform on Corporate Social Responsibility]. [online]. [Accessed $25^{\text {th }}$ June 2016]. Available from: http://narodniportal.cz/platforma-zainteresovanych-stran-csr/

[13] National Price, n.d. Národní cena ČR za společenskou odpovědnost a udržitelný rozvoj. [National Award of the Czech Republic for Social Responsibility and Sustainability]. [online]. [Accessed 30 3 th $^{\text {th }}$ September June 2016]. Available from: http://www.narodnicena.cz/narodni-cena-cr-za-csr/4

[14] National Quality Policy, (C) 2005-2009. Společenská odpovědnost a udržitelný rozvoj. [Social Responsibility and Sustainable Development]. [online]. [Accessed 25 ${ }^{\text {th }}$ June 2016]. Available from: http://www.npj.cz/cz/sekce-rady-kvality-cr/spolecenskaodpovednost-organizaci/

[15] SimilarWeb, (C) 2016. The Ultimate Market Intelligence Platform. [online]. [Accessed $25^{\text {th }}$ June 2016]. Available from: https://www.similarweb.com/pro

[16] SKÝPALOVÁ, R., R. KUČEROVÁ and V. BLAŠKOVÁ, 2016. Development of the Corporate Social Responsibility Concept in Small and Medium-Sized Enterprises. Prague Economic Papers. 25(3), 287-303. ISSN 1210-0455.

[17] SOPKOVÁ, E. and K. RAŠKOVÁ, 2012. The implementation of the concept of corporate social responsibility in the area of income tax in the Slovak Republic. E\&M Economics and Management, 15(2), 125-140. ISSN 2336-5604.

[18] STEURER, R., A. MARTINUZZI and S. MARGULA, 2012. Public Policies on CSR in Europe: Themes, Instruments, and Regional Differences. Corporate Social Responsibility and Environmental Management, 19, 206-227. ISSN 1535-3966.

[19] STEURER, R., 2010. The role of governments in corporate social responsibility: characterising public policies on CSR in Europe. Policy Sciences. 43, 49-72. ISSN 15730891. 